\title{
The Power of Persistence: Musical Advocates North of the Tweed
}

\author{
Peter Roennfeldt
}

The establishment of higher education institutions in Australia is normally an initiative of government. However, in the case of the Queensland Conservatorium of Music, the journey towards establishment was delayed continually by a government that was either unable or unwilling to accede to the increasingly vociferous demands of its musically minded constituents. The long and tortuous journey towards its opening in 1957 was characterised by the dogged persistence of numerous individuals, who today might be termed lobbyists. Without their collective efforts, the institution's arrival might have been delayed even longer than the halfcentury that elapsed between the first suggestion of Queensland having a premier music school and that concept being realised. Themes of cultural deprivation amounting to a 'state's rights' catch-cry figure strongly in the Conservatorium's story. It also became a socio-political issue as families sent their musically talented children to study at conservatoria in Adelaide, Melbourne, Sydney or overseas. The stream of agitators for a Queensland conservatorium provides an interesting snapshot of the state's musical community during the early twentieth century. This article discusses the 'power of persistence' by a several musical advocates - some of them were well-known community leaders, while the contributions of others have faded from public memory, but were no less significant.

\section{The English Connection}

Three prominent English-born colonial musicians - George Sampson, Henrietta Willmore and Richard Thomas Jefferies - are variously connected to the Conservatorium story. All three spent the majority of their long careers in Brisbane, working assiduously to build the cultural life of their adopted home. George Sampson (1861-1949) arrived in 1898 as the organist at St John's Anglican (pro-)Cathedral, a position he held until 1947. He was also a pioneering conductor of the ensembles that later became known as the Queensland State and Municipal Choir and Orchestra respectively. ${ }^{1}$ His educational contributions were also significant, commencing with his appointment as music adviser to the newly established University of Queensland in 1910. This provided Sampson with an avenue for public lectures, ${ }^{2}$ as well as representation at national conferences that later established the Australian Music Examinations Board (AMEB). ${ }^{3}$ His strong 
community presence made him a logical choice as founding president of the Queensland Music Teachers' Association in 1921, which had among its aims the goal of working 'for the establishing of a State Conservatorium of Music and a State Orchestra'. ${ }^{4}$ In his inaugural presidential address, Sampson hoped that in the future Queensland Conservatorium, emotion will be controlled by science, and that musical education by blind imitation will have substituted for it musical education by law and reason'.

Sampson's most articulate pro-conservatorium statement was published during the 1927 'Brisbane Music Week'. This festival showcased numerous musical organisations that previously were local municipal emblems, but now fell collectively under the jurisdiction of the recently formed greater Brisbane City Council. The program booklet was a virtual mission statement for cultural development, particularly Sampson's article titled 'The Need of a Conservatorium or School of Music for Brisbane'. Drawing on his English background and recent familiarity with Australian institutions, Sampson proposed support structures including 'governments, municipalities, universities and private benefactions', and infrastructure that included 'a centrally situated hall, capable of seating three or four hundred people'. ${ }^{6}$ Importantly, Sampson promoted the collegial benefits of students working in an institutional environment, as opposed to private studio tuition. He also added a political perspective: ' $[\mathrm{W}]$ ith a conservatorium Brisbane, at least, would have a chance of holding her own musically against the other States, and be a rallying point for all the musicians in Queensland.'

The Brisbane Exhibition Building's Willis pipe organ was a mutual interest for Sampson and Henrietta Willmore (1842-1938), who arrived in the city in 1864 . Best known under her first married name as Madame Mallalieu, she served as one of Sampson's precursors at St John's during the 1880 s. However, she attained greater publicity for her fundraising recitals in the $1890 \mathrm{~s}$, which helped save the Willis instrument for Brisbane. In 1930 she came out of retirement to 'test-drive' the expanded instrument, now installed in the newly built Brisbane City Hall, where it remains today. Willmore also taught music for several decades, and as a prominent suffragette served in executive roles for several women's political organisations. ${ }^{7}$ Willmore's posthumous connection to the Conservatorium would have pleased her greatly, in that young female musicians were the beneficiaries. 'Mallalieu Home' in Toowong became the official student hostel in 1958, after being gifted to the Queensland Country Women's Association from the estate of Henrietta's daughter Beatrice, and refurbished with government support. ${ }^{8}$ Until the 1980s, Mallalieu Home housed many non-metropolitan music students, and was a significant part of the Queensland Conservatorium's extra-curricular folklore. Through its history, a direct connection was maintained with the foundations of classical music in Queensland. It was demolished in the 1990s, but the link is preserved in the name of the replacement building, Mallalieu Court.

Willmore was also associated with Queensland's other major colonial import, violinist Richard Thomas Jefferies (1841-1920). Upon his arrival in 1871, they immediately forged a performing partnership that commenced with a debut recital featuring Beethoven sonatas and Mendelssohn's concerto, as well as the obligatory popular arrangements of operatic airs. ${ }^{9}$ The pair's Monday Popular Concerts also introduced much new music to Brisbane audiences. ${ }^{10}$ Jefferies 
founded the Brisbane Musical Union, directing it at various times until he retired around century's end; he also formed a family string quartet. Two daughters, cellist Mary and violinist Vada, had an ongoing professional commitment to Queensland's music until their deaths in 1949 and 1952 respectively. The Jefferies family's association with the Brisbane Chamber Society in the 1920s and the Brisbane String Orchestra that Vada directed were among their contributions. When the Queensland Conservatorium was established, it benefited immediately with a large donation of chamber music scores from the Jefferies library. ${ }^{11}$ Vada's concert master successor Max Muller also supported fundraising efforts for a scholarship in her memory. ${ }^{12}$ First offered in 1960 , it is one of the few prizes to have been offered continuously since then at the Conservatorium. Another surviving sibling, pianist Etheldreda Jefferies, also sponsored chamber music prizes in the Conservatorium's early years.

\section{Home-Grown Musicians}

Sampson, Willmore and Jefferies each influenced succeeding generations, but due to the lack of a local conservatorium, many aspiring Queensland musicians travelled elsewhere to pursue advanced studies. Percy Brier (1885-1970) achieved early success, gaining a Trinity College of London Scholarship that enabled his four years of study there from 1902. He later became a mainstay of Queensland's music as performer, teacher and AMEB examiner. An organisational leader, he was several times president of the Music Teachers' Association, which from 1930 until 1962 was known as the Musical Association of Queensland, and he also helped found a state branch of the Guild of Australian Composers. ${ }^{13}$ Having benefited personally from tertiary studies, Brier promoted the Conservatorium cause, and through his several unpublished monographs he recognised similar advocacy work by his contemporaries. Brier acknowledged that the Conservatorium's establishment came too late for his own teaching career, ${ }^{14}$ but was honoured to join its Advisory Council for several years from 1959.

Among those who left Queensland and returned occasionally was the pianistcomposer Arthur Benjamin (1893-1960). He briefly attended Brisbane Grammar School, and studied music with Sampson before travelling overseas in 1911. Benjamin's appearances in Brisbane during 1919 were short-lived, as he was soon recruited to the staff of the recently founded Sydney Conservatorium. ${ }^{15}$ After a few years, he relocated permanently overseas, initially to London where his Royal College of Music students included the young Benjamin Britten. ${ }^{16}$ Another distinguished export was Caboolture-born pianist Winifred Burston (1889-1976), who after home-schooling in music travelled to Berlin, where she studied under the famous pianist-composer Ferruccio Busoni. Returning to Brisbane in 1914 after further studies in the United States with Busoni's protégé, Egon Petri, Burston was also later appointed by to the Sydney Conservatorium staff, remaining there until her retirement in 1964. ${ }^{17}$ Burston was both an example and observer of the growing Queensland 'musical diaspora', as Sydney now became one of the main choices for talented students in the 1920s. During a Brisbane visit in 1925, Burston commented that "it was really extraordinary what a large proportion of music talent came to Sydney from Queensland'. ${ }^{18}$ 


\section{New Influences}

The musical traffic was fortunately not all one way. As in colonial times, some of Queensland's key identities in the mid-twentieth century were new arrivals. Sydney-born Robert Dalley-Scarlett (1887-1959) settled in Brisbane in 1919, after wartime overseas service and a short stint as Grafton Cathedral's organist. He was a busy conductor, teacher and composer, and also heavily involved in research into

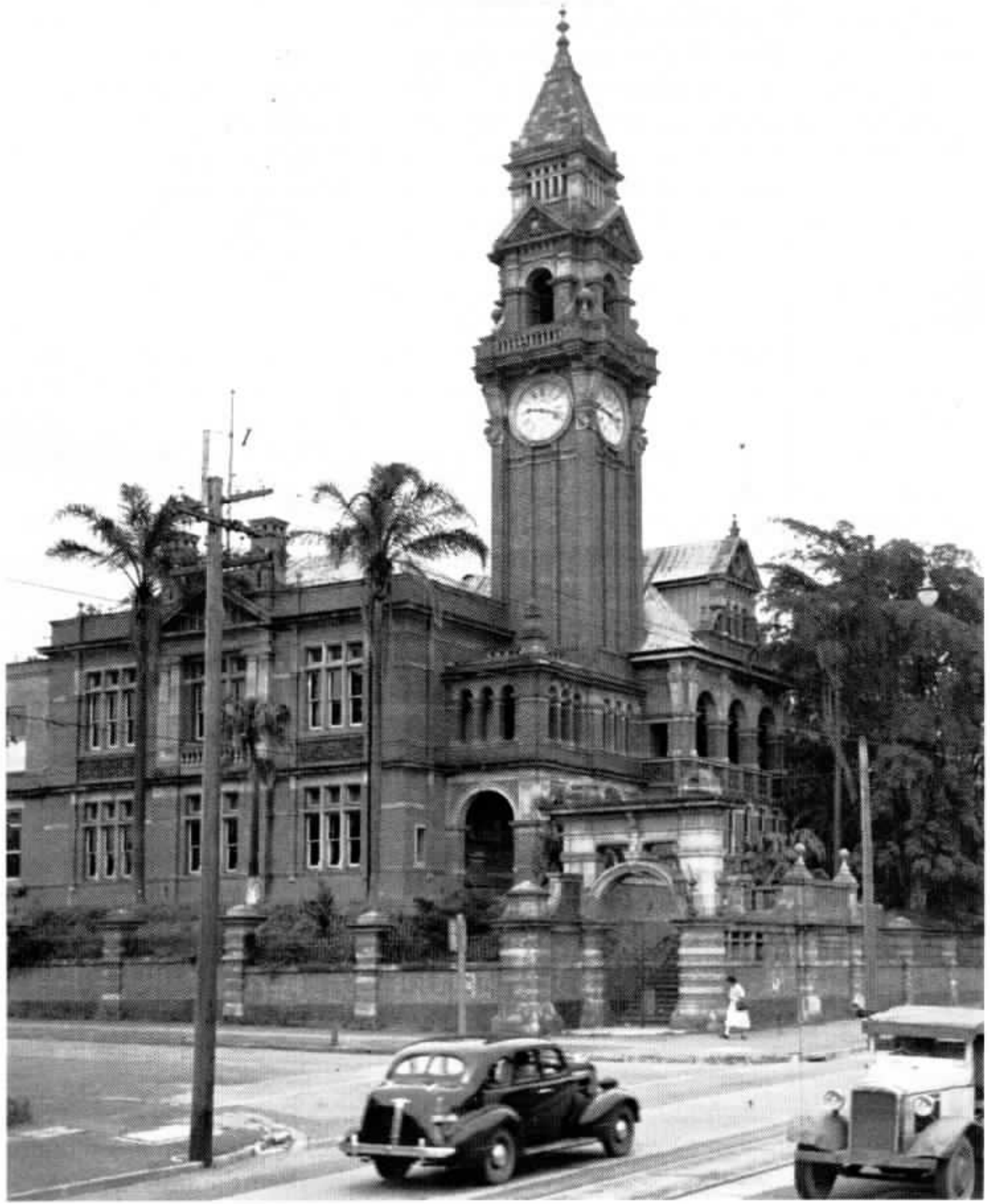

South Brisbane Town Hall on Vulture Street, South Brisbane, 1948. It housed the Queensland Conservatorium of Music from 1957 to 1975.

Source: Reproduced courtesy of the State Library of Queensland. 
the emerging field of historically informed performance practice of baroque music, particularly Händel. Unlike some who journeyed from Queensland to South Australia to study at the Elder Conservatorium, he completed by external enrolment a Bachelor degree and a Doctorate of Music in composition at the University of Adelaide. Across nearly four decades, he was an important participant in the conservatorium debate. When invited to comment in 1920 on the acting premier's pre-emptive suggestion that a conservatorium might be founded, Dalley-Scarlett stated that 'there is no authoritative body of musicians here', but that a 'central institution' could extend its scope by contributing to music teachers' professional development, and would also 'centralise the musical life and interests of the city'. ${ }^{19}$ As music critic for the Courier-Mail after World War II, Dalley-Scarlett later decried the persistent lack of musical sophistication, commenting in 1946 that 'Chopin is played like Bing Crosby'. ${ }^{20}$ The same article gave a pragmatic response to the oft-cited impediment to a conservatorium - the lack of a suitable building - claiming that Morley College under Gustav Holst started in a single room, and even the Sydney Conservatorium had been established in disused stables. ${ }^{21}$ Prophetically, he was the first to mention the South Brisbane 'Old Town Hall' as a possible site; this is where the Queensland Conservatorium initially was based during the period 1957-75. In 1954, Dalley-Scarlett claimed to have seen 'half a dozen or more movements to establish a conservatorium', which had begun 'with a Mississippi of talk' but ended 'with a trickle of words relapsing into silence'. ${ }^{22}$

As others had suggested, Dalley-Scarlett predicted that a conservatorium would have wider community benefits. One of his last concert reviews was of the 1959 visit of the Sydney Symphony Orchestra, which Dalley-Scarlett used as an opportunity to reminisce about the 1921 visit to Brisbane by the New South Wales State Orchestra. The earlier ensemble had grown out of Henri Verbrugghen's role as foundation Sydney Conservatorium director, so the clear message was that a tertiary institution could make a strong impact on community perceptions and musical standards. ${ }^{23}$ Dalley-Scarlett's posthumous connection to the Queensland Conservatorium is through a memorial scholarship, which since the early 1960s has supported the further studies of several alumni. His death in July 1959 also initiated another long-standing direction, when his position as Courier-Mail music critic passed to foundation Queensland Conservatorium director William Lovelock, who recently had left the institution amid widespread furore. 'Dr Bill' continued to comment on Queensland's music until he returned to England in 1982, resulting in a scenario where for more than 30 years Brisbane's 'paper of record' employed, in turn, two Doctors of Music as its chief concert reviewers.

\section{Other Advocates}

Not all conservatorium advocates were musicians. During Verbrugghen's first Brisbane visit in July 1920, Catholic Archbishop James Duhig (1871-1965) convened an 'enthusiastic meeting' of supporters, who resolved to 'form a committee to further the scheme'. ${ }^{24}$ Nearly 30 years later, he criticised the ongoing lack of cultural infrastructure, proposing that 'a well-designed conservatorium would enhance the beauty of the Botanic Gardens'. ${ }^{25}$ This was another prophetic statement, in that Gardens Point became the site of the Queensland Conservatorium's 
second campus during the period 1975-96. The occasion for this comment was a piano recital by Leah Horwitz, who soon became another Queensland expatriate studying in Sydney. She was one of the few who returned to Brisbane, later also teaching at the Queensland Conservatorium including several years as its head of keyboard. Leah's father, Myer Horwitz (1894-1963), was another long-standing advocate fora conservatorium, having attended the inaugural meeting to discuss starting a conservatorium'. ${ }^{26}$ In later life, he recalled a conversation from the 1920s with Queensland Governor Sir Matthew Nathan, who commented that a tertiary institution would raise music-teaching standards throughout the community. Horwitz was one of the many music lovers whose professional career lay outside the arts, but whose passion fed the increasingly popular movement. His contribution was recognised through an invitation to attend the Premier's conference on the conservatorium issue in $1955 .{ }^{27}$

\section{State Government Initiatives}

Until World War II, the issue was prosecuted mainly in the media and in educational circles, including the university and music teacher networks. The $1940 \mathrm{~s}$ saw early encouraging signs of government support for cultural development, which in the absence of an arts ministry was conducted through the state Education Department. ${ }^{28}$ This was mainly due to the Director-General, Lewis David Edwards (1885-1961), for whom the arts were an essential element of a well-rounded education. ${ }^{29}$ His achievements included expansion of primary school music education through the appointment of a team of specialist teachers based throughout the state, and also the foundation in 1944 of the Queensland State String Quartet (QSSQ), which performed about 300 school concerts annually as well as professional concerts. ${ }^{30}$ The conservatorium connection emerged through the quartet's first leader, violinist Ernest Llewellyn (1915-1982), who until the formation of the Queensland Symphony Orchestra (QSO) in 1947 was the state's most senior public service musician. The seminal document he submitted to Premier Hanlon, entitled 'Proposal for Establishment of a Conservatorium of Music in Brisbane' accordingly was more likely to gain a fair hearing than earlier well-meaning protestations. Dated 28 October 1947, the proposal stated that despite the advent of the QSO and the QSSQ, "our musical development has been and is being constantly retarded'. ${ }^{31}$

The detailed document addressed the various issues of location, governance models, the need for scholarship funding, curriculum, staffing and physical resources. Echoing Sampson's arguments of 20 years previously, Llewellyn reinforced the importance that the conservatorium atmosphere and environment plays in the training and education of musicians'. Queenslanders were beginning to make claims associated with Brisbane's new status as Australia's third-largest city, ${ }^{32}$ something to which Llewellyn referred in response to rumours of a Newcastle branch being planned by the State Conservatorium of New South Wales. Unfortunately, Llewellyn left Queensland in 1948, but his subsequent contribution as the founding director of the Canberra School of Music from 1965 could well have been informed by his Brisbane manifesto. 
The need for a conservatorium was reinforced by large attendances at the Summer Schools organised for several years from 1946 by Sydney May (d. 1968) on behalf of the University of Queensland. Held mostly at Toowoomba's Glennie School, they continued until 1953, by which time the University of Queensland was no longer the sponsor. Because of various guest lecturers' status as staff of interstate conservatoria, and high enrolments of up to 200 students, the Summer Schools became a lightning rod for Queenslanders' frustrations regarding the lack of a conservatorium. It became very obvious that attendees would not be able to pursue further intensive training in their home state. May's complex model of a regionally networked 'Master School of Music' confused the issue somewhat, ${ }^{33}$ but some would have sympathised with his view that 'a Conservatorium of Music in Brisbane is of little, if any more value to a student in Cairns than one in Sydney or any other city'. ${ }^{34}$ Due to his position as a University of Queensland lecturer and AMEB organiser, May was appointed to the government's 1951 Committee of Inquiry, and in 1955 to the inaugural Conservatorium Advisory Council. Despite his earnest support, May's irascibility led to his resignation in protest from the Council within weeks of the Queensland Conservatorium's opening in 1957 . He complained about the calibre of the full-time lecturers, whose appointment had been determined largely by director Lovelock. ${ }^{35}$

May's comrade-in-arms, Les Edye (d. 1961), was president of the Musical Association of Queensland during the critical juncture of 1950. Anticipating preelection commitments by both the Liberal opposition leader and Premier Hanlon, ${ }^{36}$ Edye took proactive steps to mount a conservatorium fundraising campaign. Utilising his statewide teacher networks, the Queensland Conservatorium or School of Music Fund commenced work immediately after the election, with local committees established in 22 centres as far north as Cairns and west to Charleville. The initial goal of between $£ 2000$ and $£ 3000$ (the equivalent of $\$ 90,000-\$ 130,000$ today) was achievable, but the eventual goal of $£ 10,000$ was probably overly ambitious. $^{37}$ As this initiative evolved, dissent arose regarding perceptions of Edye's and May's plans to establish 'nothing more than a coaching establishment for singers and for players upon the piano and violin, with the conduct of examinations in music as its chief business'. ${ }^{38}$ In November 1956, the fundraisers presented a cheque for $£ 264311 \mathrm{~s} 6 \mathrm{~d}(\$ 73,000)$ to the premier; this was used to establish the Queenslanders' Foundation Scholarship, ${ }^{39}$ which supplemented three governmentfunded tuition-waiver scholarships offered respectively in piano, strings and voice. The first Foundation Scholar was Gympie-born Gwynneth Williams (later Sitcheff), who coincidentally received the first lesson ever delivered at the Conservatorium on its first day of teaching, 18 February $1957 . .^{40}$

The extent of public sentiment on the issue is demonstrated by a concerted letter-writing campaign initiated in 1949 by numerous women's groups and other organisations. Many of these organisations figure in the later history of the Conservatorium through sponsored scholarships; they included the Theosophical Order of Service and the Brisbane Women's Club. A recurring theme was the cultural and familial loss of 'their children to the South for tuition', and the disadvantage experienced by those unable to relocate. Support was evidenced further by a deputation coordinated by the National Council of Women, which claimed to represent about 90 organisations. Education Minister Bruce confirmed 
his personal support and intention to take their case to Cabinet. ${ }^{41}$ Of particular interest is the connection with the Business and Professional Women's Club of Brisbane, ${ }^{42}$ whose then secretary, Patience Thoms (1915-2006) later served as Griffith University's Deputy Chancellor. Her membership of the Conservatorium's Advisory Council following the Conservatorium's amalgamation with Griffith in 1991 would particularly have pleased her, as would the knowledge that the scholarship in her memory was later held by an Honours student whose research focused on the institution's history. ${ }^{43}$

The women's lobby also figured in a light-hearted series of articles published during January 1953 under the banner 'If Women Ran Queensland'. Speaking as a hypothetical Minister of Arts and Culture, violinist Gloria Foley (1924-95) proposed the establishment of a conservatorium with purpose-built facilities and the 'appointment of professors for all branches of studies ... and provision of scholarship arrangements to enable young Queenslanders to take up these studies'. ${ }^{44}$ Foley was yet another Queenslander who had pursued musical studies elsewhere. On returning to Brisbane, she had to explain that her plans to study in Prague had taken an unexpected turn, since she arrived there only weeks before the 'Bloodless Revolution' of February $1948 .{ }^{45}$ Despite the privations of a communist regime, the benefits she gained were summarised succinctly upon her return: she stated that Queensland's greatest need was a single word - 'conservatorium'.46 Foley performed frequently at the Conservatorium during the $1960 \mathrm{~s}$, in chamber music concerts promoted by the Musica da Camera Society. With her celloplaying Czech husband, Jiri Svoboda, she also performed with Conservatorium lecturer Rex Hobcroft, both locally and in regional centres such as Warwick and Toowoomba. Foley and Svoboda also later formed the Pro Musica quartet with Conservatorium lecturer Ladislav Jasek and Director Basil Jones. ${ }^{47}$

By the $1950 \mathrm{~s}$, the conservatorium issue had transcended the arts community and was decidedly political, which may account for the prominence of Foley, whose father sat in state parliament for about 40 years. During 1950, while Gloria was overseas, Foley suggested in parliament that a conservatorium would be more cost-efficient and 'something on a bigger scale' than the trainee Opera Scheme that existed at the time. ${ }^{48}$ Other state ministers were obliged to comment, such as John Duggan, Minister for Transport and the local Member for Toowoomba. When opening the 1951 Summer School, Duggan stated that the government was 'anxious to establish such an institution' but was currently constrained from taking immediate action. ${ }^{49}$ The following year he proudly reported that progress was occurring in the form of an official investigation. ${ }^{50}$ More often, the premier and Education Minister were targeted. A quirk of history was that the result of Premier Hanlon's 1950 election pledge, the 1951 Committee of Inquiry, wound up only weeks before his premature death in office in January 1952. The premiership then passed to his deputy, Vince Gair, who presided at the Conservatorium's opening in February 1957, in what was possibly his final positive act before the notorious Labor split that would end his state political career. The most vociferous state member was Tom Aikens (1900-85), who held various seats in Townsville over his 30 -year parliamentary career. ${ }^{51} \mathrm{~A}$ belligerent regionalist, and also an enthusiastic amateur singer, he constantly questioned the value of a Brisbane-based conservatorium. ${ }^{22}$ He returned to this 
theme often, ${ }^{53}$ and also stressed the financial disadvantage to those obliged to travel to the 'Brisbane conservatorium'. ${ }^{54}$

The role of the fourth estate should also not be under-estimated. The journalistic contributions of Dalley-Scarlett have been noted earlier, but those of Ernest Briggs of the Sunday Mail ${ }^{55}$ and Tom Mead of the Courier-Mail were significant too. ${ }^{56}$ Then a junior reporter, David Bray also commented occasionally, ${ }^{57}$ previewing his more substantial role as reviewer of Conservatorium performances during the 1980s and 1990s. Surpassing the efforts of all these supporters was the dogged enthusiasm of Frederic Rogers (d. 1985), who in the post-war decade published nearly 50 pieces in the Brisbane Telegraph. Never missing an opportunity, Rogers' most purple prose was summoned in late 1951, when the news of a conservatorium branch being opened in the regional city of Newcastle drew forth some parochial breast-beating, as seen in the headline, 'A piece of News that Should Make Brisbane Blush: Big City Takes a Bad Beating' ${ }^{58}$ Following the Conservatorium's opening, he reinforced the input of the Telegraph, whose support of the conservatorium cause was sampled by citing one headline from each year since $1946 .{ }^{59}$ Rogers continued his commentary on the Conservatorium through regular reviews, which from 1959 until his death over 25 years later appeared mostly in the Sunday Mail. ${ }^{60}$

The Queensland Conservatorium of Music's opening ceremony on Saturday, 16 February 1957 was attended by a VIP list that symbolised the previous halfcentury's machinations and campaigning. The political realm was represented by the premier and the entire state Cabinet, including key ministers such as former and current Education Ministers Devries and Diplock, and Deputy Premier Duggan. The entire Advisory Council was present, including its chairperson, Education Director-General HG Watkin, public servant Douglas Fraser - who would later assume the chair - the familiar figures of Edye and May, and the ABC's Queensland manager, David Felsman. Membership also included two businessmen, AJ McKennariey and TJ Weedman, whose Allan and Stark department stores sponsored a strings bursary that continued when the business was rebranded as Myer Queensland. Other benefactors present included the trustees of the Emily Hammond Scholarship, named after a well-known expatriate singer. The entire Conservatorium staff attended, including Director William Lovelock, pianist Rex Hobcroft, violinist Basil Jones and singer Peter Martin, and sixteen part-time teachers, including well-known musicians Gordon Spearritt, Robert Boughen, Una Morgan, Nora Baird and Archie Day, as well as seven QSO members who taught the orchestral instruments.

Churches were represented by Anglican and Catholic Archbishops Halse and Duhig, as well as the Presbyterian moderator and Council of Churches president. Brisbane City Council support was acknowledged in the presence of Lord Mayor Groom and Alderman Dean, who oversaw the council's extensive community music program. The University of Queensland's claim to be the rightful host institution for a conservatorium, which was a live proposition until 1953, was represented by Chancellor Hirschfield, and its then solitary music lecturer, Hugh Brandon. Other organisational leaders were John Ellis from the Musical Association, and the presidents of three other 'Queensland' bodies, the Eisteddfod Council, the State and Municipal Choir and the Country Women's Association. 
Press included Frederic Rogers and Roger Covell, then junior music critic for the Courier-Mail, though Dalley-Scarlett appropriately attended in his own right. Completing the list of around 130 attendees was the most important group, the thirteen full-time students who embodied the ambitions of so many conservatorium advocates. Unlike their forbears, they no longer had to leave Queensland for advanced training. Only one came from Far North Queensland, but significantly she held one of the prestigious scholarships. ${ }^{61}$ The confines of the South Brisbane Town Hall would not have permitted the attendance of any part-time students, then approaching 200 in number, who would comprise the majority of enrolments until the Conservatorium moved to Gardens Point in 1975.

The Conservatorium's establishment was heralded as 'a new and important advance in the State's cultural and educational development', ${ }^{62}$ and potentially the 'State's musical headquarters'. ${ }^{63}$ The first report, published within hours of the opening ceremony, likewise described 'an important day in the cultural history of the State', ${ }^{64}$ epitomised by the presence of so many of Queensland's leaders. Though many participants in the conservatorium campaign never met each other, their collective sense of purpose evinced a community spirit that transcended generations and political realities. The power of persistence by the conservatorium's many individual advocates had become a self-evident reality. Significantly, its heritage as a 'state' icon survived its amalgamation with a larger institution, and is recognised today in its official title, Queensland Conservatorium Griffith University.

\section{Endnotes}

1 Betty Crouchley, 'Sampson, George (1861-1949)', Australian Dictionary of Biography, Vol. 11 (Melbourne: Melbourne University Press, 1988), pp. 514-15.

2 George Sampson, 'Shape in Music', Education Office Gazette, vol. XIII, no. 1 (1921): 42-8 and vol. XIII, no. 2 (1921): 77-84.

3 Noel Wilmott, 'A History of the Music Department University of Queensland 1912-1970', unpublished MA qualifying thesis, University of Queensland, 1986, pp. 2-3.

4 'Proposed Music Teachers Association', The Musical and Dramatic Times and Cinema Record, 18 December 1920: 5.

5 George Sampson, 'First Presidential Address', The Musical and Dramatic Times and Cinema Record, 4 June 1921: 2.

6 George Sampson, The Need of a Conservatorium or School of Music for Brisbane, program booklet for Brisbane Music Week, 9-15 October 1927, p. 26.

7 Betty Crouchley, 'Willmore, Henrietta (1842-1938)', Australian Dictionary of Biography, Vol. 12 (Melbourne: Melbourne University Press, 1990), pp. 513-14.

8 Muriel Pagliano, Country Women: History of the First Seventy Years (Brisbane: Queensland Country Women's Association, 1998), pp. 192-3.

9 'Evening Concert', Brisbane Courier, 1 February 1872: 1.

10 Robert K Boughen, 'Jefferies, Richard Thomas (1841-1920)', Australian Dictionary of Biography, Vol. 9 (Melbourne: Melbourne University Press, 1983), pp. 472-3.

11 'To Honour Musician', Courier-Mail, 24 October 1957: 7.

12 John Ellis, 'Brisbane', Australian Musical News, 2 January 1957: 23-4.

13 Robert K Boughen, 'Brier, Percy (1885-1970)', Australian Dictionary of Biography, Vol. 7 (Melbourne: Melbourne University Press, 1979), p. 412. 
14 Percy Brier Memoirs, n.d., Book 10 (1955-1958), Percy Brier Papers, Fryer Library, University of Queensland.

15 'Music, Drama, and Pictures', Brisbane Courier, 25 October 1919: 16.

16 Charles Campbell, 'Benjamin, Arthur Leslie (1893-1960)', Australian Dictionary of Biography, Vol. 7 (Melbourne University Press, 1979), pp. 262-3.

17 Larry Sitsky, 'Burston, Winifred Charlotte Hillier Crosse (1889-1976)', Australian Dictionary of Biography, Vol. 13 (Melbourne: Melbourne University Press, 1993), p. 316.

18 'A Queensland Musician', Brisbane Courier, 29 April 1925: 23.

19 'Conservatorium of Music - Mr. Scarlett's Views', Daily Mail, 15 April 1920: 4.

20 Robert Dalley-Scarlett, 'Chopin is Played Like Bing Crosby', Courier-Mail, 1 March 1946: 2.

21 Robert Dalley-Scarlett, 'Music Conservatorium: Could Start in a Room', Courier-Mail, 2 March 1946: 4.

22 Robert Dalley-Scarlett, 'The Only Way to Start is ... to Start', Courier-Mail, 17 February 1954: 2 .

23 Robert Dalley-Scarlett, 'Sydney's Symphony is a Virtuoso Orchestra', Courier-Mail, 4 June 1959: 8 .

24 'Conservatorium for Queensland', Sydney Morning Herald, 24 July 1920: 12.

25 'Park as Gallery Site', Courier-Mail, 30 January 1948: 3.

26 'He Fostered Music Love', Courier-Mail, 11 July 1963: 7.

27 Myer Horwitz, personal papers, n.d. (c. 1955), Queensland Conservatorium Griffith University, Brisbane.

28 The Department of Public Instruction (created in 1875) became the Department of Education in 1957. It is currently the Department of Education and Training.

29 Tom Watson, 'Lewis David Edwards: The "Philosopher-Director", 1937-1951', in Soldiers of the Service Vol. 3: Mid Twentieth Century Queensland Educators (Brisbane: History of Queensland Education Society, 2006), p. 34.

30 Adrian Thomas, 'From Little Acorns: The First Queensland State Quartet, 1944-1948', Australasian Music Research, vol. 8 (2004): 59-72.

31 Ernest Llewellyn, 'Proposal for Establishment of a Conservatorium of Music in Brisbane', unpublished paper, 1947.

32 William Hatherell, The Third Metropolis: Imagining Brisbane Through Art and Literature 1940-1970 (Brisbane: University of Queensland Press, 2007).

33 Frederic Rogers, 'Conservatorium Needed for Musical Progress', Brisbane Telegraph, 2 February 1946: 1 .

34 Sydney May, 'Music and the State', Forward: The Magazine of the New Education Fellowship Queensland Section, December 1938: 13.

35 “'Bungling" Charged in Music Row', Courier-Mail, 23 February 1957: 3.

36 Queensland Conservatorium or School of Music Fund - Provisional Committees, May 1950, Department papers, Queensland State Archives.

37 'Aim to Raise $£ 13,000$ for Music School', Courier-Mail, 28 March 1950: 3.

38 Frederic Rogers, 'Please! Nothing Less than a Real Conservatorium!' Brisbane Telegraph, 1 April 1950: 4.

39 VC Gair, Memorandum to LF Diplock, 29 November 1956, Department papers, Queensland State Archives.

40 'Gympie Pianist, 19, Took First Lesson', Courier-Mail, 19 February 1957: 8.

41 'Music Need Expounded, Brisbane Telegraph, 20 September 1949: 11. 
42 Patience Thoms, 'Conservatorium Need', Brisbane Telegraph, 26 June 1950: 4.

43 Elizabeth Sims, 'The Queensland Conservatorium of Music: An Analysis and Review of Its Representation Within Historical Literature', BMus Studies Honours thesis, Queensland Conservatorium Griffith University, 2005.

44 'If Women Ran Queensland, They Would ..., 12 January 1953: 6.

45 'I Lived Behind the Iron Curtain', Courier-Mail, 2 June 1951: 2.

46 'Recital Tour is Her Aim', Courier-Mail, 1 June 1951: 8.

47 William Lovelock, 'New quartet is very creditable', The Courier-Mail, 21 Jul 1966, p. 6.

48 TA Foley, 'Appropriation Bill, speech in Queensland parliament, 5 December 1950, Official Records of the Debates of the Legislative Assembly, Vol. 199 (1950-51), pp. 1748-9.

49 'Summer School of Music Officially Opened', Toowoomba Chronicle, 8 January 1951: 4.

50 'Summer School of Music Opens with Record Attendance', Toowoomba Chronicle, 7 January 1952: 5.

51 lan Moles, A Majority of One - Tom Aikens and Independent Politics in Townsville (Brisbane: University of Queensland Press, 1979), pp. 46-7.

52 JA Turner, 'Address in Reply', speech in Queensland Parliament, 24 August 1950, Official Records of the Debates of the Legislative Assembly, vol. 198 (1950-51), pp. 190-1.

53 Tom Aikens, 'Conservatorium of Music in Country Towns', speech in Queensland Parliament, 26 August 1954, Official Records of the Debates of the Legislative Assembly, vol. 209 (1954-55), p. 132.

54 Tom Aikens, 'Students Attending Conservatorium of Music, Brisbane', speech in Queensland Parliament 14 October 1955, Official Records of the Debates of the Legislative Assembly, vol. 212 (1955), p. 713.

55 Ernest Briggs, 'Brisbane's Music Still in a Rut', Sunday Mail, 21 December 1952: 15.

56 TF Mead, 'Conservatorium has Passed Dream Stage', Courier-Mail, 24 February 1948: 2.

57 David Bray, 'One Hundred and Five Music Lovers Can't Be Wrong', Courier-Mail, 16 January 1953: 2.

58 Frederic Rogers, 'A Piece of News that Should Make Brisbane Blush: Big City Takes a Bad Beating', Brisbane Telegraph, 3 November 1951: 4.

59 Frederic Rogers, 'Frederic Rogers Records: The Birth of the Con', Brisbane Telegraph, 23 February1957, p. 15.

60 John Villaume, 'Fred Rogers Fearless Fighter', Courier-Mail, 26 March 1985: 18.

61 'Lot Closer to Their Musical Ambitions', Courier-Mail, 14 February 1957: 11.

62 'State Aid for Music', Courier-Mail, 13 February 1957: 2.

63 'Worth a Fanfare', Courier-Mail, 16 February 1957: 1.

64 'Conservatorium Seen as State Cultural Event', Brisbane Telegraph, 16 February 1957: 3. 


\title{
Queensland Review
}

\section{Editor}

Belinda McKay

\author{
Editorial Board \\ Patrick Buckridge \\ Belinda McKay \\ Advisory Board \\ Denis Cryle \\ Kay Ferres \\ Mark Finnane \\ Richard Fotheringham \\ Jock Macleod \\ Yorick Smaal
}




\section{Queensland Review}

Queensland Review is published with the support of the School of Humanities, Griffith University.

Views expressed in Queensland Review are those of the authors and do not necessarily represent those of the editors or board.

Contributions should be sent to:

Dr Belinda McKay

Editor, Queensland Review

School of Humanities

Griffith University

Nathan QId 4111

Email: B.McKay@griffith.edu.au

ISSN: $1321-8166$

\section{Cover Picture:}

This photo was taken from the top of the clock tower at South Brisbane Town Hall, looking towards Stanley Street, during the 1893 floods. In the centre is the Ship Inn Hotel. In the left foreground is 'The Cliffs': the South Brisbane Registry Office is at the extreme right front, with the home of $\mathrm{Dr}$ Thomas $\mathrm{P}$. Lucas between it and the Ship Inn. All buildings other than the Ship Inn were in what is now South Brisbane Memorial Park.

Source: Photo courtesy of John Oxley Library, photo no. 78099.
Queensland Review is a multi-disciplinary journal of Australian Studies which focusses on the history, literature, culture, society, politics and environment of the state of Queensland.

Invitation to contribute and information for authors are printed on the inside back cover.

Subscription Rates 2011 This journal is published biannually.

\section{Individual}

Australia

\section{Institutions}

\section{Australia}

Overseas

All prices are in Australian dollars and include economy air postage and GST where applicable.

Orders and subscription enquiries should be addressed to:

Journal subscriptions

Australian Academic Press

32 Jeays Street

Bowen Hills Qld 4006 Australia

Published by

AUSTRALIAN ACADEMIC PRESS:

32 Jeays Street Bowen Hills QLD

4006, Australia

www.australianacademicpress.com.au 


\section{Review}

VOLUMe 18 NUMBER 12011

Editorial

V

Belinda McKay

Articles

'A Blood-Stained Corpse in the Butler's Pantry':

The Queensland Bush Book Club

Robin Wagner

Harmonising the City: Music, Multiculturalism

and The Muses' Magazine in Brisbane

Patrick Buckridge

The Power of Persistence: Musical Advocates

North of the Tweed

Peter Roennfeldt

South Brisbane Memorial Park: A Memorial to What?

Bill Metcalf

Magic Moments: Contextualising Cinema Advertising

Slides from the Queensland Museum Collection

Lara Cain Gray

All the Waters of Lethe: An Experience of Female

Alcoholism in Federation Queensland

Alana Piper

Notes on Contributors 


\section{Notes on Contributors}

Patrick Buckridge teaches literature in the School of Humanities at Griffith University. He has published widely on Australian literature and reading, and is the author of a biography of Brian Penton (1994) and co-editor, with Belinda McKay, of a literary history of Queensland (2007).

Lara Cain Gray has held teaching, research and curatorial positions in Australia and the United Kingdom, including a period as Curator of the Australia and New Zealand collection at the British Library. Her most recent role was as Curator of Cultures and Histories at Queensland Museum.

Bill Metcalf is a Brisbane-based freelance researcher and writer, a member of the Professional Historians Society and Research Methodologist within the Griffith Graduate Research School. He is on the editorial boards of several refereed academic journals, and is the author of nine books, nineteen chapters in edited books, six articles in encyclopedias, 25 refereed articles in academic journals, nineteen reviews in refereed journals, over 50 articles in magazines and newspapers, plus numerous conference papers and research reports.

Alana Piper is a PhD candidate at the University of Queensland, currently researching a thesis on female criminal subcultures in late nineteenth and early twentieth century urban Australia. She has previously published work in the Journal of Australian Studies, Crossroads and the Queensland History Journal.

Peter Roennfeldt is Professor of Music Literature and immediate past Director of the Queensland Conservatorium Griffith University. His interest in local musical history commenced with an Honours dissertation on Robert Dalley-Scarlett at the University of Queensland, and was reignited recently through a recording collaboration with the State Library's Music Queensland project. His forthcoming monograph on the history of the Queensland Conservatorium will be published by Australian Academic Press.

Robin Wagner is Library Director at Gettysburg College, Pennsylvania. She earned a BA in History from Dickinson College, a Master's degree in Library Science from the University of Kentucky and a Master's degree in Liberal Studies from Dartmouth College. During 2008, she undertook research on the correspondence and surveys associated with the Munn-Pitt report in Australian libraries, archives and public record offices. 